\title{
Adjusting to High Inflation: The Israeli Experience
}

\author{
Zalman F. Shiffer
}<smiles>[10BH]</smiles>

URING the last decade, many countries have experienced relatively high rates of inflation. In response to this persisting phenomenon, people have changed their payment habits, restructured their portfolios and increasingly resorted to different forms of indexation.' Since inflationary episodes have differed across countries, it is not surprising to find variations in the degree and nature of inflationary adjustment across countries.

The Israeli experience with inflationary adjustment is of particular interest because Israel has experienced relatively long, high and variable inflation and, in response, has developed an elaborate system of inflationary adjustment. Israel experienced two periods of high inflation during Word War II and during the first years of its independence: the annual rate of inflation averaged about 27 percent between 1939 and 1943 and about 34 percent between 1950 and 1953. Between 1954 and the end of the 1960s, the rate of inflation was reduced to a relatively mild 5 percent per year. In the 1970s, however, inflation accelerated rapidly (see table 1 ); it averaged about 40 percent per year between 1973 and 1978,125 percent between 1979 and September 1983, and over 400 percent during 1984." In

Zaman F. Shiffer is a senior economist at the Bank of lsrael and a former visiting scholar at the Federal Reserve Bank of St. Louls. The author wishes to thank Leslie Ballis Koppel and David J. Flanagan for research assistance and the members of the Research departments at the Federal Reserve Bank of St, Louis and the Bank of Israel for helofu comments. The views expressed in this article do not necessarily reflect the views of either institution.

For discussions of the costs and consequences of infiation, see Fischer (1981), Fischer and Modigliani (1978), Kleman (January 1984 ) and Tatom (1976).

For discussions of the acceleration of intation in Israel, see Bruno and Fischer (1884), Fischer (1984, 1985), Livatan and Pheman (1984) and Shifer (1982).
July 1985, the Ismaeli government embarked on a stabilization program, which has reduced inflation to an annual rate of 27 percent between July 1985 and May 1986.

The Israeli public and its govermment have responded to this inflationary experience in a variety of ways:

1) The introduction and application of indexation to a wide variety of economic transactions. Wage indexation was introduced during World War II. During the $1950 \mathrm{~s}$, the govemment indexed both its long-term debt and long-term loans to the public: indexation of life insurance was also introduced. In 1975, indexation was applied to tax brackets and tax exemptions. In addition, indexation is now applied to other transactions, including construction and rental contracts, some short-term loans, and property insurance.

2) Varations in the use of indexation. Thus, for example, indexation of long-term loars from the government to the public was practically abandoned in the 1960 s and gradually remtroduced in the 1970 s.

3) Variations in the frequency of price and other adjusments. Thus, for example, the frequency of payment of the Cost of Living Allowance on wages increased from every six months in the mid-19ros to every month by the and of 1984.

4) Variations in the "rate of indexation," 1.e.. in the extent to which indexed prices were adjusted. Thus, the rate of indexation for wages increased from 70 perent in the nid-1970s to $80-90$ percent in the 1980s; at the same tima the fate of indexation of tax brackets increased from 70 percent to 100 percent

The Israeli covernment has plaved a relatuely large role in Israel's adjustment to intation. For additional discussion of the adjustment of the lstaeli economy to inflation, and, in particular, of the problems of indexation, see Brenner and Patinkin (1977). Cukieman (1985) Fischer (1985), Keman (1977, Juy 1984), Oded Livatan (1982 1985). Shifier (1984) and Sokoler (1985). 


\section{Table 1}

\section{Inflation in Israel 1960-84} (annualized changes in the CPI, based on December data)

\begin{tabular}{|c|c|}
\hline Period & Rate of Inflation \\
\hline $1960-69$ & $5 \%$ \\
\hline $1970-72$ & 12 \\
\hline $1973-74$ & 40 \\
\hline $1975-76$ & 30 \\
\hline $1977-78$ & 45 \\
\hline 197980 & 122 \\
\hline 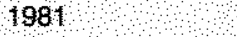 & 101 \\
\hline 1982 & 131 \\
\hline 1983 & 191 \\
\hline 1984 & 445 \\
\hline $1985(\mathrm{Aug}-\mathrm{Dea})$ & 37 \\
\hline 1986 (Jan-Nay) & 17 \\
\hline
\end{tabular}

SOURCE, Central Bureau of Statistics statistical Abstract of Israel.

5) Tax reforms aimed at imposing corporate income taxes on inflation-adjusted profits.

6) Intensive financial innovation and important changes in the structure of financial portfolios.

7) Changes in the mix of economic activity such as the allocation of more economic resources to financial and tax management.

The purpose of this article is to discuss some problems that Israel has faced under conditions of high and rising inflation, how it has tried to adjust to them, and some shortcomings of the solutions adopted with special reference to the last decade. The first section discusses, in general terms, the effects u. inflation on price adjustment and the use of indexation. The next section deals with wage indexation in Israel and discusses the effects of the adoption of partial indexation. The third section investigates the effects of inflation on taxation and the partial adjustment of the tax system to inflation in Israel. In the fourth section, we analyze how financial and asset markets have reacted to inflation under conditions of imperfect adjustment in the tax system and in government financial transactions.

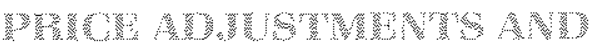

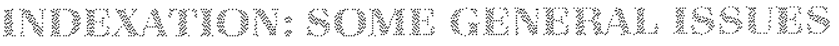

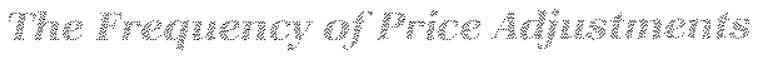

In most makets, prices are not continuously ad- justed to changes in demand and supply; rather, they are maintained for a certain period of time before being adjusted by sellers, buyers, negotiators or regulators. Price-setters decide how often to change prices by comparing two kinds of costs associated with such changes: (a) the cost of changing the price, including possible reactions of customers, competitors and the general public (or the authorities) ${ }^{4}$, and (b) the loss associated with not adjusting the existing price in view of changing market conditions. The price will be changed when the latter outweighs the former.

Any price that remains unchanged during an inflationary period decreases relative to the prices that are rising. Consequently, ptice-setters typically will find that unchanged prices will deviate more rapidly and by larger amounts from their (changing) optimal prices, the higher the rate of inflation. They will also find that their customers will increase their purchases when prices are relatively low, forcing larger fluctuations in the price setter's production or inventories. ${ }^{.}$ Hence, it is not surprising that, as inflation has accelerated, Israeli producers have adjusted their prices more frequently. The Israeli govemment has also adjusted more frequently its managed rate of foreign exchange, the prices of its services and the prices of private goods that it regulates.

\section{Fy}

The administrative cost of price adjustment can be reduced if the price is adjusted routinely according to some relatively simple rule. The choice of a particular price adjustment rule depends on operating costs of

"Customers generally find freguent price adjustments inconvenient; moreover, price-setters may be uncertain about the reactions of their competitors as well. in addition, public opinion sometimes condemns price increases because the public believes that they are "unfair" or because they believe in the cost-push view of inflation. In Israel, the public especially opposed increases in the prices of government-controlled food items.

In one famous episode, the Israeli public began hoarding pubic telephone tokens when it recognized that the adjustment of token prices was tong overdue. The government, which owns the telephone company, "relused to give a prize to speculators"; instead of faising the price of the tokens, it produced more tokens. Of course, these immediately disappeared irom the market as well. Thus, the government incurred unnecessary production costs for the "extra" tokens and kept the prices of its service too low for too long. Meanwhile, the general public chose to hoard the tokens rather than to use the public telephone system. When the government finally raised the price of the tokens, they reappeared in the market.

FFor rigorous discussions of the conditions under which this reaction will prevall, see Galyam and Hanoch (1984) and Sheshinski and Weiss (1977, 1983). Galyam and Hanoch (1984) report that the average frequency of private price adjustments in israel increased from 3.3 times per year in 1973 to 5.1 times per year in 1979 . 
alternative rules, and on the extent to which they approximate the path of price changes that would be chosen if there were no adjustment custs. In certain cases, the price-setter may even decide to announce his price adjustment rule to provide potential customers with useful information.

One simple rule would be to increase prices over time at some predetermined rate. Thus, for example, between mid-1975 and September 1977, the Israeli government devalued the exchange rate at an almost constant rate of 2 percent per month.

As an alternative, price adjustment can be based on indexation; prices can be increased by a percentage that is equal - of at least related - to the rate of change of a specific standard for example, a price index). Thus, construction contractors in Israel often index their prices to the "cost of construction index." In recent years, many firms and traders have started quoting their prices in terms of U.S. dollars. This amounts to a daily adjustment of the Shekel (Israeli currencyl price in terms of changes in the rate of exchange between Shekels and U.S. dollars. Between 1979 and 1982, the government generally carried out a policy of "indexation" of the rate of exchange. According to this policy, the Israeli currency was devalued at the rate that was roughly equal to the difference between the domestic and foreign rates of inflation, thus, trying to stabilize the relative price of tradeable vs, other goods.

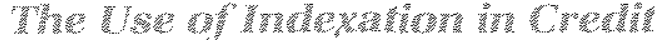

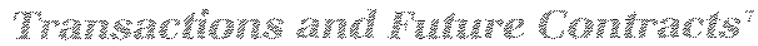

The most important use of indexation in Israel has been in credit transactions and other future contracts - situations that involve contractual obligations for future payments. Parties to such contracts are generally concemed with the real value of payments (i.e. the price deflated valuel, and not with their nominal value. If they expect the general price level to change, they can adjust the nominal value of the stipulated future payments to achieve their desired future expected real level. Thus, in the case of a loan, the parties can add an "expected inflationary premium" to the rate of interest. If the rate of inflation deviates from its expected level, however, the real value of the future payments will be different from that assumed when the contract was made.

For feferences to the large body of literature dealing with problems of indexation, see, for example, Dombusch and Simonsen (1983) and Fischer (1983) and McNelis (1985).
As an altemative, parties to a contract can index future payments using some mutually agreeable method. In this case there is no uncertainty about the real value of future payments (measured in terms of the standard used for indexation); the nominal payments, however, will be unknown in advance.

The choice between these two systems of adjustment depends on several considerations:

(1) The confidence that the public has in its expectations about the behavior of prices during the contract period. This confidence depends on the expected variation in the rate of inflation and on the length of the contract period.

(2) The extent to which the value of the parties' portfolios and their flows of income and consumption react to changes in prices. Thus, for example, if a borrower expects that the nommal value of his income and assets will not be affected by variation in the rate of inflation during the loan period, he will be reluctant to index his loan."

(3) The perceived cost of introducing and operating indexation. This cost depends on the degree to which indexation arrangements have been used in the economy in the past.

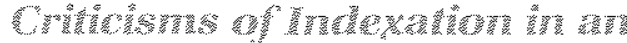

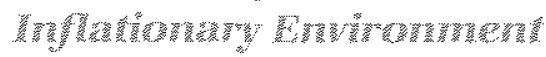

The use of indexation is sometimes criticized on the grounds that it may not produce the same results that would occur under frequent, low-cost readjustments. This criticism applies, in principle, to all predetermined formulas for price adjustment, and should be weighed against the benefits of contractual relationships. Indexation, however, is different from other price adjustment formulas, because it may produce relative price rigidities that cannot be overcome by higher rates of inflation lunless indexation is incomplete). This problem is especially acute when the economy is subject to strong, non-reversible shocks like the energy price shocks in the 1970s. By retarding the adjustment of relative prices, indexation may compound the real effects of such shocks."

It has sometimes also been argued that indexation introduces an inflationary bias into the economy. By exacerbating the process of the economy's adjustment to a non-reversible exogenous shock, for example,

Since, by assumption, his assets and incomes are not indexed, he will obviously lose weath from unexpected inflation; however, his loss would be greater if his obligations were indexed. See Levhari and Liviatan (1977).

9See Gray (1976) 
indexation may increase unemployment and create pressures for more expansionary policies. Moreover, because indexation transmits price changes rapidy throughout the economy, thereby augmenting the short-run effects of temporary disturbances on the genenal price level, it may create pressures for accommodating policies. Finally, to the extent that it reduces the perceived costs of inflation, indexation may weaken the public's opposition to inflation.

On the other hand, it might be argued that, if the tax system and govemment debt are indexed, the government will have less incentive to create inflation. Also, the cost of anti-inflationary policies could be lower when contracts are indexed, since unexpected disinDation will not cause unexpected increases in the real value of wages and interest payments."

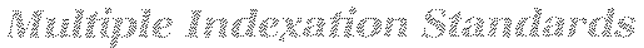

While it might seem convenient to use a single standard of indexation for all purposes, such a uniform index will not be optimal for all transactions if different prices rise at different rates. In such cases, multiple indexation standards may be preferable; this has occurred in Israel. The Israeli government imposes indexation to the consumer price index (CPI) in most of its own tansactions and in contracts that it regulates. The private sector also uses the CPI to index some of its transactions. Indexation to specific indus try price indexes, however, is also used, especially in construction contracts." Occasionally, people will use some ad hoc index that reflects conditions associated with a specific contract mote closely than do the genemaly published price indexes. Finaly, indexation to the rate of exchange of a foreign currency lohiefly the U.S. dollat has become more popular in recent years. It is especially common in shorterm financial transactions and in transactions between private nonfinancial parties. Fims engaged in foreign trade also index their transactions to the rate of exchange.

Considemations goveming the choice of the stand ard of indexation depend on the nature of the transaction involved and, in principle, are similat to those

\footnotetext{
10This effect is stronger, the higher is the rate of indexation and the frequency of its application. See Fischer (1983) and Friedman (1974).

11The government had relected proposals to index is loans to specific industry indexes. Proponents of this type of indexation argued that it would both reduce the industries' risks and suppress price in creases, because price-seiters who raised prices would be penalzed by higher debt repayment. The obvious drawback of this ype of indexation is that is creates incentives for ineficient resource use.
}

affecting the choice between indexation and nominal price adjustment formulas discussed above. Since different indexes may increase at different rates (especially in the short run), the chotce of the indexation standard affects the allocation of risk between the parties to a contract. ${ }^{12}$

In Israel, the extent of the use of different standards of indexation has varied over time in reaction to changes in the mix of economic activity and the experience with the performance of different indexes. Thus, for example, the use of the U.S. dollar as a standard of indexation dechned substantially follow ing a large devaluation in the eary 1960s; it has regained popularify with the transition to frequent devaluations since the mid-1970s. In recent years, this indexation has spread rapidly for two reasons. Finst it allows frequent adjustments since the rate of $\mathrm{ex}$ change is changed and published caily; price indexes, on the other hand, are calculated monthly and published with a two-week delay. At higher rates of inflation the value of frequent price adjustments outweighs the disadvantage of using an index that may not rellect exactly the costs and revenues of the contracting parties. Second, the use of foreign exchange as a standard of deferred payments was also enhanced by its increased use as a means of exchange and a temporary abode of purchasing power isee below!.

\section{WHA}

Wage indexation was introduced to Israel during World War II. It is based on a Cost of Living Allowance (COLA) agreement negotiated between the labor unions association and the major private employers association. The provisions of the COLA agreement are extended, by government decree, to workers and enployers that are not represented at COLA negotiations.

The provisions of the COLA have varied considerably over time. Their present structure is based on recommendations of a committee estabhished in 1975 by the govemment, the labor union association and the employers federation. This commitee recommended that the COLA be adiusted at six-month intervals by 70 percent of past C.PI increases, provided that the CPI has increased by at least 5 percent during

\footnotetext{
Tenerally speaking, the indexation standard is one of the negotiabte provisions of a contract. The choice of the standard depends both on the perceived risks involved and on the expected rates of increase of gifferent indexes.
} 
the relevant period. The committee decided against 100 percent indexation on the grounds that the COLA should not compensate wage-earners for changes in indirect taxation and in foreign prices - two disturbances that were supposedly associated with 30 percent of the price increases prior to $1975 .^{\text {t4 }}$

As the rate of inflation accelerated, the minimum interval between payments was reduced, first to three months and, by 1984, to one month. The rate of indexation was also increased; the COLA by 1984 provided 80 percent compensation for accumulated CPI increases of at least 12 percent during one month or more, and 90 percent compensation if the CPI increased by 25 percent in a single month.

The parties did not always abide strictly to the formal COLA. Thus, in some periods of unanticipated acceleration in inflation, the workers received additional ad hoc payments. On the other hand, the labor unions accepted a reduction in the rate of indexation at the end of 198 and beginning of 1985 as a patt of an anti-inflationary "package deal." In July 1985, COLA payments were suspended for three months in the early stage of the antinintationary program. The former $\mathrm{COL} A$ agreement was reintroduced thereafter, as the minimum price increase necessary to migger payments was even reduced to 4 peecent. In May 1986 , however, the rate of indexation was reduced 1070 percent and the migger increased again to 7 percent.

As a result of the different constmants to which it has been subject, the COLA generally has not compensated Israeli workers fully for past price increases. According to some calculations, real wages would have decreased by an average of about 9 percent per year between 1973 and 1982 if wages were increased only according to the COLA arrangements land inflation was unaffected.$^{5}$ Due to other wage components, real wages in effect rose by some 25 percent in that period.

\footnotetext{
13This constraint (which formerly had been a 3 percent threshold) turned out to be ineffective because inflation was higher than 5 percent. For other properties of the COLA agreement see Keiman (July 1984) and Liviatan (1982).

${ }^{\star}$ Over the years, there have been heated discussions about the purpose of wage indexation in israel. Some have argued that it should prevent real wage erosion; others have argued that it should maintain the share of wages in national income. The decision of the 1975 committee was closer to the latter view; it could also be interpreted as an attempt to compensate workers only for monetary disturbances and not for real disturbances. See Gray (1976) and Keiman (July 1984).

${ }^{15}$ See Kleiman (July 1984 ) and Liviatan (1982).
}

Wage indexation in Israel provides, however, a convenient interim working rule for the adjustment of wages between contacts that are negotiated annually or bi-annually. In these negotiations, labor and management agree on a basic wage rate, which then will be atutomatically adjusted by the COLA during the contract period. The paties are aware that the COLA does not fully compensate the workers for past price increases, and the wage negotiations are affected by the parties' estimate of the expected erosion of the real wage level during the contract period. The higher the expected rate of inflation and the lower the rate of indexation, the higher is the increase in the base wage rate agreed upon in the wage contract. Moreover, the higher the rate of real wage erosion due to the inadequacy of the COLA, the greater is the real wage increase derived from other components of the wage contract. ${ }^{26}$

The partially indexed wage determination system in Israel has two additional effects. First, it creates a cycle in real wages; they reach their maximum level when the new contract is signed and fall thereafter. There are also smaller cycles between COLA adjustments. At high lates of inflation, this system produces considerable fluctuations in real wages. Under such conditions, workers can either adjust their real expenditure pattems of stabilize their real expenditures over time by adjusting their financial portfolios.

Second, because the parties to the wage contract cannot anticipate exactly the rate of inflation, their negotiations result in the determination of an $e_{x}$ pected average real wage mate for the contract period. If the rate of inflation deviates from its expected level, the real wage rate will be different from its expected level, producing disequllibrium in the labor market. Thus, it is argued that in some cases the government has clelibenately adopted more inflationary policies aimed at erroding "excessive" real wage increases by exploiting the imperfections of the COLA agreement. Uncertainty about future real wage levels obviously affects both the demand and the supply of labor. If workers are more risk-averse than employers, this may result in higher average real wage levels and lowes employment.

Even if we abstact from the last argument, it is clea: that the alleged excessive real level of wages in Ismel is not due to excessive indexation, since real wages have

\footnotetext{
:For statistical tests bearing on these relations, see Kleiman (July
} 1984 ) and Liviatan (1982). 
Table 2

\section{Average Tax Rates on Wage Income in Israel, 1976-84'}

\begin{tabular}{|c|c|c|}
\hline & $\begin{array}{l}\text { Effective income tax } \\
\text { as percentage of fixed } \\
\text { real wage income at } \\
\text { average } 1975 \text { level }\end{array}$ & $\begin{array}{l}\text { Effective net direct taxes } \\
\text { as percentage of fixed } \\
\text { real wage income at } \\
\text { average } 1975 \text { level }\end{array}$ \\
\hline 1976 & $13 \%$ & $9 \%$ \\
\hline 1977 & 12 & 8 \\
\hline 1978 & 13 & 9 \\
\hline 1979 & 15 & 12 \\
\hline 1980 & 17 & 15 \\
\hline $198 \pi$ & 13 & 10 \\
\hline$\$ 982$ & 15 & 13 \\
\hline 1983 & 15 & 13 \\
\hline 1984 & +7 & 15 \\
\hline
\end{tabular}

Calculated for a marred wage-earner with two chidren

Including income taxes, social security contributions and children's allowances.

SOURCE: B.O.I. Annual Report 1982 Table V-8, 1984 Table V-7 (Hebrew).

increased secularly despite the real erosion due to partial indexation. On the other hand, indexation can be considered as part of the inflationary mechanism under conditions of accommodating monetary policies. However, as argued above, high wage indexation can also facilitate anti-inflation policies by preventing real wage increases during the disinflation process.

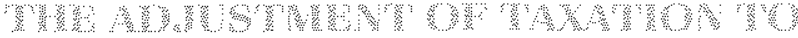

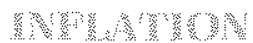

Inflation affects taxation through two channels: effective tax rates and the tax base. Both are discussed in this section.

\section{Whak}

Israel has traditionally taxed nominal income at progressive rates - i.e, rates which increase with the level of nominal income. Taxpayers with unchanged real income drift into higher tax brackets as their nominal incomes increase; as a result, they pay a higher percentage of their income in taxes the real value of exemplions erode in a similar fashioni. Because the effective tax rates on diferent incomes do not increase proportionally during inflation, the aftertax distribution of income is affected as well.

Up to 1975 , the adjustment of Israeli tax brackets and exemptions to inflation was essentially ad hoc. Since then, they have been formally indexed to the CPI. Between 1975 and 1979, tax brackets and exemptions were raised at six-month intervals by 70 percent of the past period's inflation. In 1979-80, the degree of indexation was raised to 100 percent and the frem quency of its application increased to every three months. In 1984, this frequency was increased to match that of the COLA paid on wages. As shown in table 2, however, incomplete indexation of tax brackets and exemptions has resulted in an increased tax burden for wage-earners who, unlike some other taxpayers, cannot postpone their tax payments. Table 2 shows also that accelerations of inflation in 1979-80 and 1984 were accompanied by increases in the lax burden (its fall in 1981 was due to an extra adjustment of the brackets).

The effective rates of taxation depend on more than the actual rates alone; they are also affected by the lag between the time when the tax lability is created and when it is paid, and on the interest rate charged for that period. The required frequency of tax payments, as well as the interest rates and fines charged on tax arrears, were only gradually adjusted when inflation accelerated. As a result, many taxpayers were able to reduce the real value of their tax payments. According to Bank of Israel (B.O.I.) estimates, this effect produced a $\$ 480$ million reduction in real tax revenue as inflation accelerated from 190 percent in 1983 to 445 percent in 1984 . This amounts to about 2 percent of GNP, about equal to the govemment revenue from money creation in recent years.

\section{Tha The Base}

Business taxation in Israel has traditionally been based on the difference between gross revenue and nominal historical costs incurred in producing this revenue. Under conditions of price stability, this base is a reasonable approximation for the theotetical concept of income as the potential increase in net wealth - that is, the amount that could be consumed without affecting net wealth. ${ }^{\mathrm{T}}$

When prices increase, the deduction of historical nominal costs of production from taxable income results in an increase in the real tax base, even if the real values of costs and sales are unchanged. For example, assume that, during a period of stable prices, production costs are 350 Ispaeli shekels at the begin-

${ }^{17 S e e ~ H i c k s ~(1946), ~ c h a p . ~} 14$. 
ning of the year and the product is sold for 500 Shekels at the end of the year. The firm's taxable income is 150 Shekels of 30 percent of its sales. Now, assume insteat that all prices double during the year, and the firm's sates are 1,000 shekels; its taxable income will thus be 650 Shekels or 65 percent of its sales even though its costs and sales are unchanged in real terms. Thus, if income taxation is imposed on the nominal difference between revenues and costs, real net wealth will be taxed at income tax ates that exceed the explicit tax rates on wealth.

One important example of the effect of inflation on the tax base is the taxation of interest income. When inflation accelerates, nominal mates of interest increase to compensate for the etosion of the principal loaned. Taxing the inflation-induced portion of the interest payments resulls in taxing the principal of the loan. Symmetrically, borrowers who can deduct the inflation-induced component of their interest payments from their taxable income receive a tax break.

The inflation-induced rise in the nominal rate of interest increased the difference between the beforetax and after tax interest rates paid by borrowers who could beneft from the full tax advantages. ${ }^{14}$ As a result, there were strong incentives to redirect economic activity and to restructure portfolios to minimize income from highly taxable interest and to increase taxdeductible interest payments. In particular, private businesses relied more heavily on debt fnancing; interest payments were tax-deductible, while dividend payments were not.

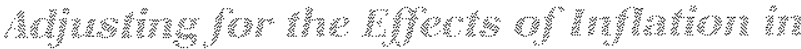

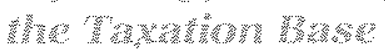

Over the years, the Israeli government has introduced several measures to compensate, at least partially, for the effect of inflation on the real tax base used for business taxation. First, an allowance for accelerated estimates of fixed capital investment depreciation costs for tax purposes shifted the timing of tax payments to later periods when the real value of the given nominal payments is lower. Second, allowances for expenditures on inventory were authorized. Thind, lower tax rates were applied to some forms of

1aThe difference between these two rales is equal to $(t) \times(i)$, where $t$ is the tax rate and $i$ is the nominal rate of interest. According to the B.O.l. calculations, the difference between real before- and after-tax short-term interest rates increased from 4.5 percent in 1983 to 12 percent in 1984. See B.O.I. Annual Report 1984, table VII-10. "inflation-induced nominal revenues" - revenues that reflect only the adjustment of nominal values to the change in prices and therefore are not real gains. Thus, inflation-induced capital gains were taxed at a relatively low flat rate of 10 percent. Similarly, indexation payments on govemment-issted, indexed financial assets were exempt from laxes, and the holders of these assets were required to pay laxes only on the real interest receipts. Fourth, the govemment has pattially imposed income taxation on the inflationinduced income gained from low interest loans granted by business to their owners and employees.

These tax adjustments were not applied universally and were only partially related to the effect of inflation on the tax base. Thus, they did not completely neutralize the adverse effects of the tax system under inflationary conditions.

In 1982, Istael adopted the "Taxation under Inflationary Conditions Act" to ensure that business taxation would be applied only to the increase in the neal net worth of the taxpayer. To achieve this result; the new law provided that:

a) the fim be granted a capital preservation allowance deduction on the difference between the value of its assets which are subject to nominal laxation and its liablities, if this difference is positive.

b) if the firm's liabilities are largen than the assets subject to nominal taxation, a proportional part of its interest payments will not be tax-deductible."

The idea behind the new law, in principle, was simple and elegant. Many of its provisions were complicated, however, and it considerably increased efforts devoted to tax management. Because of the ambiguity of some of its provisions, many fims discovered that they were able to control the level of their tax returns. Instead of increasing tax collection, as the government had infended, the new act resulted in

\footnotetext{
While some tax payments are deferred, the Israeli firm is, in principle, subject to full taxation of the nominal appreciation of certain assets (like inventories) and to taxation of the real (inflationadjusted) appreciation of other assets (like physical capital). On the credil side of its balance sheet, it can deduct fully the interesi (and indexation) payments on its liabilities, but cannot deduct expenses against its equity capital.

Under this system, there is no positive or negative taxation of the firm's real nef worth if the (reevaluated) value of the assets that are subject to full nominal taxation is equal to its liabilities. However, if the value of the subject to full nominal taxation assets exceeds is less than) the value of the liabilities, the present system results in partial positive (negative) taxation of the firm's real net worth. The intention of the iwo recommendations was to prevent this positve or negative real net worth taxation.
} 
lower real tax receipts, Thus, the B.O.I. estimated in its 1984 annual repont that the new law reduced real lax revenue by the equivalent of $\$ 350$ million labout 1.5 percent of GNP) between 1983 and 1984.

In 1985, a committee appointed by the government recommended the abandonment of the taxation under the Conditions of Inflation Act and the adoption of a new system. According to these recommendations, corporate taxpayers (and some other businesses) will be required to submit reports based on accounting carried in terms of U.S. dollars or constant purchasing power Shekels ladjusted daily. Other taxpayers will be required to adjust their units of account monthy or even more often if inflation remains in the twomdigit monthly ange.

Early reactions to these recommendations pointed to considemably increased costs of tax management (with special difficulties for firms that carry their accounting on an acchual rather than a cash basis). The adoption of these recommendations could have affected considerably the rest of the economy and, in particular, impinged on the monetary regime. Thus, constant purchasing-power shekel accounting would have encouraged further CPI indexation throughout the economy, while bollar accounting would have resulted in a full "Dollarization" of the staeli econ omy. As mentioned earlier, the Ismell economy had anyway been subject to "crawling Dollarization" for" a number of years. ${ }^{3}$ In view of the sizable recent reduction in the inflation rate, it seems that these new recommendations will not be applied.

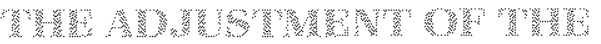

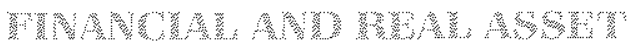

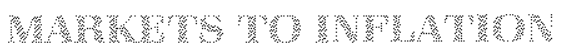

Adjustment of private portolios of assets and hiabil ties to inflation has been strongly affected by tax considerations, by the nature of the government intervention in financial markets and the incomplete adjustment of the govemment's fnancial activities to inflation.

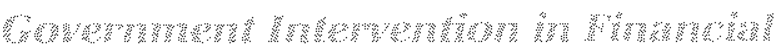

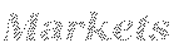

The Israel government intervenes heavily in hade-

\footnotetext{
20. Between 1983 and 1985 , there were heated discussions about the merits of adopting official Dollarizalion as a shortout for rapid disintlation.
}

cial markets in attempting to affect the allocation of resources in the economy. By closely controlling the process of long-term financial intermediation, the government functions, in effect, as a huge fnancial intermediary. It raises funds directly and indirectly from the private sector; it uses part of these proceeds to finance its own deficit and directs the rest as loans to private borrowers under closely controlled conditions. The public sector pays relatively high rates of return to savers and allocates funds to favored activities such as business fixed investment, exports and housing at lower rates of intenest. The difference between the government borrowing and lending rates represents a subsidy that is fimanced through the government budget.

Since the 1950s, most government bonds and longterm financial savings, which ane lasgely backed by govemment bonds, have been indexed (primarily to the CPI ." Shot-term deposits indexed to the rate of exchange of different foreign currencies are supplied to the private sector by the B.O.I. Government loan indexation was also introduced in the $1950 \mathrm{~s}$, but it was discontinued in the 1960 s and reintroduced only gradually during the 1970 s (becoming again the general fule by 1981 ) In addition, the nominal rates of interest charged on non-indexed government loans were only belatedly and partially adjusted to inflation during the $1970 \mathrm{~s}-$ as can be seen from table $3^{2.3}$

As could be expected, firms and individuals made considerable effort to qualify for public loans offered at increasingly negative real rates of interest during the 1970s. The terms of these loans had important, sometimes very inefficient, effects on the direction of economic activity and the distribution of income and wealth, hindering the development of private capital markets and contributing to the increase in government deficis. Thus, the 1984 B.O.I. annual repont estimated that the value of subsidies and transfers granted by the authorities to eredit borrowers aver-

\footnotetext{
21 Parialy indexed government bonds were issued between 1975 and 1982. The partial indexation, however, was applied in a way that ensured positive real rates of retum at any rate of infiation.

22 in 1962 a 67 percent devaluation produced a large teal increase in the value of the (then widespread) foreign exchange indexed loans. The government renegotiated the tems of the loans in lavor of the borrowers. Thereater: if introduced devaluation and indexation insurance options whose premiums were relatively low. Thus, indexation of government loans practicaly disappeared for many years.

${ }^{23} \mathrm{Ey}$ the end of the period, the low nominal rates of interest shown in table 3 applied only to a small (and highly subsidized) proportion of public toans.
} 
Table 3

\section{Inflation and Nominal Rates of Interest in Israel, 1970-82}

\begin{tabular}{lcccc}
\hline & $\begin{array}{c}\text { Average } \\
\text { yearly } \\
\text { rate of } \\
\text { inflation }\end{array}$ & $\begin{array}{c}\text { Intest } \\
\text { rate on } \\
\text { short-term } \\
\text { "free" } \\
\text { commercial } \\
\text { bank credit" }\end{array}$ & $\begin{array}{c}\text { Interest on } \\
\text { subsidized } \\
\text { long-term } \\
\text { loans to } \\
\text { manufacturing }\end{array}$ & $\begin{array}{c}\text { Interest on } \\
\text { subsidized } \\
\text { long-term } \\
\text { loans on } \\
\text { mortgages }^{3}\end{array}$ \\
\hline $1970-72$ & $10 \%$ & $16 \%$ & $9 \%$ & $7 \%$ \\
$1973-74$ & 29 & 22 & 9 & 8 \\
$1975-76$ & 35 & 29 & 12 & 10 \\
$1977-78$ & 42 & 46 & 19 & 12 \\
$1979-80$ & 103 & 162 & 30 & 12 \\
$1981-82$ & 119 & 155 & 30 & N.A. \\
\hline
\end{tabular}

Increase in average yearly Consumer Price Index (see Table 1 for December to December rates of inflation).

Interest on approved overdraft facilities.

${ }^{3}$ Over the years, indexation was increasingly applied to subsidized loans, and, by the end of the period, these low nominal rates applied only to a small part of public loans.

SOURCE: Meir Sokoler (1985).

aged 4 percent of GNP in $1974-78,9$ percent in 1979 80 , and 5 percent in 1981-84. It is difficult, however, to determine how much government spending on subsidies to borrowers reflected discretionary policy and how much was the result of unanticipated inftation."

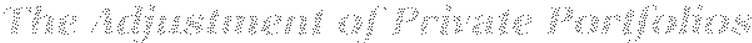

As increased inflation raised the cost of holding money, people began to economize on their money holdings in predictable ways. They changed their payment patterns by matching more closely their receipts and payments; they increasingly resorted to the use of overdraft facilities and relied more on interest-bearing assets, rather than money, as temporary abodes of purchasing power. Transaction costs incurred in shifting among different assets became relatively unimportant when compared with the increasing differences between rates of retum of money and other assets. Table 4 shows how the real value of money balances has decreased during the vears of high inflation despite positive GNP growth.

24See Cukierman (1985), Litvin and Meridor (1983) and Sokoter (1985). Litvin and Meridor estimated that unplanned inflationary transfers from the government to borrowers averaged about 4 percent of disposable income in 1975-80.
As inflation accelerated, the Israel public shifted manly from money to indexed assets rather than to non-indexed, interest-bearing assets like time deposits and certificates of deposit (CDs). The public's preference for indexed money substitutes was due, to a large extent, to the availability of two types of relatively liquid indexed assets - tradeable CPI indexed govenment bonds and short-term deposits indexed to the rate of exchange. These assets semved as hedges against unexpected inflation. In addition, short-run fluctuations in their real values were kept for many years within a relatively narow range by official intervention. ${ }^{25}$

Table 4 shows that the value of money and unindexed short-term deposits increased considerably in 1985. This was due to the steep reduction in the rate of inflation in the second part of the yeat and to policyinduced increases in the real retum on unindexed deposits.

25See Shiffer (1982) for a discussion of this policy. The preference for govermment-backed indexed assets was also affected by different tax treatment of the indexation differentials on these assefs and the nominal interest on unirdexed deposits. Correction of this tax discrimination in the early 1980 s increased the demand for unindexed assets; their share in the public's portfolios, however, remained relatively low untit recently. 
Table 4

\begin{tabular}{|c|c|c|c|}
\hline Period & $\begin{array}{l}\text { Money } \\
\text { supply }\end{array}$ & $\begin{array}{l}\text { Unindexed } \\
\text { money } \\
\text { substitutes }\end{array}$ & $\begin{array}{l}\text { Indexed } \\
\text { money } \\
\text { substitutes }\end{array}$ \\
\hline 1970 & 302 & 243 & 418 \\
\hline 1972 & 391 & 300 & 489 \\
\hline 1974. & 309 & 137 & 794 \\
\hline 1976 & 280 & 81 & 649 \\
\hline 1978 & 268 & 64 & 875 \\
\hline 1980 & 140 & 51 & 914 \\
\hline 1982 & 113 & 136 & 1000 \\
\hline 1984 & 75 & 127 & 1186 \\
\hline 1985 & 94 & 315 & 958 \\
\hline
\end{tabular}

Components of the lsrael $\mathrm{M}_{4}$ monetary aggregate December data

$2^{*} \mathrm{M}^{\mathrm{B}}$ - currency and non interest bearing onecking accourits

Unindexed time deposits certificates of deposits and the "shot term loan" (an unindexed $\mathrm{B} O \mathrm{OL}$ bill).

Foreign exchange indexed deposits of Israel residents in domestic banks (excluding deposits created by personal restitution payments fom the $F$ R of Germany) and marketable indexed government bonds:

SOURCE B OI annual reports and other $B$ OI data

Under conditions of high and variable inflation people are especially reluctant to hold illiquid assets that do not offer a reasonable hedge against unexpected inflation. Such assets are now practically nonexistent in Israel. On the other hand, the Israeli public has acquired considerable amounts of fully indexed longuterm financial assets, such as closed saving dem posits and different kinds of pension and insurance funds that are backed primarily by government debt. Thus, despite high and rising inflation, the government has been able to finance part of its deficit through domestic debt sales. Domestic debt financing averaged some 5 percent of GNP in the $1974-84$ period - about the same as in the $1968-73$ period. ${ }^{26}$

Besides indexed domestic financial assess, direct claims against foreigners and physical assets can also serve as hedges against inflation. Claims against foreigners can be held in the form of cash, international traveler's checks, deposits abroad, foreign securitios,

25 See Bruno and Fischer (1984) and B.O.I. annual reports, table VIII-2 (1983 and 1984). etc. The holding of such assets is legally limited in Israel, but there are strong indications that the legal constraints are not always strictly observed. In particular, foreign exchange is often used illegally as a means of payments among Israeli residents, of between Israeli residents and foreign visitors. This use apparently has risen in recent years along with the increased indexation to foreign exchange in the Israeli economy. Between 1983 and the first half of 1985 , the demand for foreign exchange increased as many is raelis became concemed about the possible taxation of domestic financial assets. The demand for foreign exchange increased also as it became evident that, with 400 percent annual inflation fate, monthly indexation of many financial assets to the CPI may not provide adequate protection against inflationary erom sion. According to some early indications, the adoption of the 1985 stabilization plan has brought about the reduction in the asset demand for foreign $\mathrm{ex}$ change.

The avallability of indexed financial assets land foreign claims) has reduced the demand for physical assets, like housing as hedges against inflation. Since 1973 , the demand for these assets also was adversely affected by reduced real GNP and population growh. On the other hand, physical investment has been encouraged by the availability of cheap government loans. Table 5 shows that the average increase in the real value of physical assets held by the public has lagged behind that of financial assets (excluding unecorded claims against foreigners) be tween 1973 and 1984 .

In the late 1970 s and ealy 1980s, lsmel experienced an unprecedented boom in its stock market. This experience was, at least, partially related to the effects of inflation. Due to the inflationary taxation of their nominal profits, banking concerns suffered losses in their real equity value. In addition, they were unable to raise adequate funds through unindexed assets and were not allowed to compete with the government in the indexed bond market. They resorted, therefore, to manipulation of the market prices of their shares in order to increase the attractiveness of new share issues. This activity had destabilizing effects on the stock market, and the banks were frnally forced to discontinue their manipulation in October 1983. At that time, the real value of bank shares fell sharply.

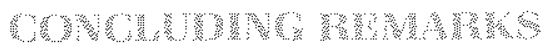

The Ispeli puble and its government have responded in a variety of ways to the long inflationary 
Table 5

\section{Increase in Financial and Physical Assets Held by Israeli Public, 1979-84 (real annual growth)}

\begin{tabular}{lccc}
\hline Period & $\begin{array}{c}\text { Financial } \\
\text { assets }\end{array}$ & $\begin{array}{c}\text { Physical } \\
\text { assets }\end{array}$ & $\begin{array}{c}\text { Of which } \\
\text { housing } \\
\text { property is }\end{array}$ \\
\hline $1970-73$ & $13.2 \%$ & $16.7 \%$ & $26.8 \%$ \\
$1973-78$ & 9.7 & 6.8 & 6.6 \\
$1978-84$ & 6.3 & 3.8 & 5.7 \\
$1970-84$ & 9.0 & 7.5 & 10.2 \\
\hline
\end{tabular}

SOURCE: Dan Yariv (1984); B.O.l calculations.

experience to which the country has been subject and in particular, to the acceleration of inflation over the past decade. Israel has adopted a variety of social contrivances intended to reduce, at least partially, some of the effects of unanticipated inflation. The most important of these contrivances have been the different indexation devices described in this article.

The adjustment of the Israeli economy to rising inflation has been long, arduous and incomplete. As partial measures were applied, new problems emerged; often, partial adjustments created new inefficiencies. Genemally speaking, the $1970-85$ period of high and rising inflation in Istael has been characterized by very infensive financial activity, by frequent shifts of financial demands between markets and by rapid financial innovation. Firms, and individuals to a lesser extent, restructured their assets and liabilities to benefit from the imperfect adjustment in the public sector's financial operations and the tax system. All lold, considenable resources were invested in financial and lax management rather lhan more productive activities. For example, the share of finance and busi ness services employment rose from 52 percent in 1970 to 9.5 percent in $1984 .^{27}$

Because of its elaborate infation-adjustment mechanisms, Ismael has been able to avoid major economic breakdowns despite its unfavorable intation experience. The economic performance of Ismat has, how-

${ }^{27}$ Kleman (January 1984) and Marom (1986) estimated hat some 24 percent of 1982 GNP was directed to financial inflation-adjustment activities. ever, clearly deteriorated in the 1970 s and early 1980 s. $^{2}$ While other factors also have contributed to this result, there can be no doubt that high and rising inflation and imperfections in inflation adjustment have adversely affected economic efficiency and contributed to the deterioration of the country's economic performance. ${ }^{3 / 3}$

As a result, there has been growing recognition in Israel that price stability is a more attractive policy alternative than aftempting to find ways to adjust to high inflation:" Thus, by mid-1985, Israel began an ambitious antiminfationary program that has poduced many encouraging initial results.

As Inflation went down, people have begun to change gradually the habits and institutions that were adopted during the high inflation years. These changes have so far been limited by the people's concern about the possibility of reinflation. There is a strong feeling that inflation-adjustment mechanisms should be curbed further in the future to support a sustainable lower rate of inflation. Some of the changes that have been adopted under the pressure of inflation, however, may also prove beneficial in a more stable environment. Thus, for example, some sort of financial indexation may contribute to the smooth and efficient operation of long-term financial markets.":

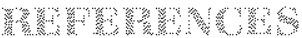

Auerbach, Zvi, and Nahum, Patrick. "The Effects of Inflation on Tax Collection," The Israeli Tax Review (September 1985), pp. $37 \div-76$ (Hebrew).

Bank of israel. Annual reports (Hebrew and English).

Bremer. Reuven, and Don Patinkin. "Indexation in Israel," in Erik Lundberg, ed., Inflation Theory and Anti-Inflation Policy (London: Macmillan, 1977), pp. 387-416.

2ulsrael has avolded the breakdown in its democratic potitical system and the massive impoverishmen of large social classes that has often accompanied high-inflation episodes in other countries. The effect of inflation on Israels income and weath distributions, however, has been far from neutral; in particular, the imperfect adjust ment of taxation and govermment tending policies have produced impontant consequences.

${ }^{29}$ Thus, real economic growth fell from 10 percent per year in the $1961-72$ period to 3 percent in the 1973-84 period (and even less in the 1980s); the rate of unemployment increased from $3 . A$ percent in $1970-72$ to 5.1 percent in $1982-84$ and private savings from all sources decreased from 36 percent in $1970-72$ to 28 percent in 1982-84. The reduction in gross national savings has been much more acute because of increased govemment deficits.

sosee Fischer (1985)

${ }^{31}$ See Shiffer (1984). 
Bruno, Michael, and Stanley Fischer. "The Inflationary Process in Israel: Shocks and Accommodation," in Yoram Ben-Porath, Michael Bruno and Nadav Halevi, The Economy of Israel: Maturing Through Crises (The Maurice Falk Institute for Economic Research in Israel, Jerusalem, July 1984), pp. 508-57.

Cukierman, Alex. "Indexation and the Political Economy of the Israeli Inflation," prepared for the 60th Annual Conference of the Western Economic Association, Anaheim, California (May 1985).

Dormbusch, Rudiger, and Mario Henrique Simonsen, ed., Inflation. Debt and Indexation (MIT Press, 1983).

Fischer, Stanley. "Towards an Understanding of the Cosis of Inflation: II," in Kafl Brunner and Allan H. Meltzer, eds., The Costs and Consequences of Intlation, Camegie-Rochester Conference Series on Public Policy, Vol. 15 (North Holland, Amsterdam, Autumn 1981), pp. $5-41$.

....... "Indexing and Inflation," Journal of Monetary EConomics (November 1983), pp. 519-41.

"The Economy of IsFael," in Kart Brunner and Allan $\mathrm{H}$. Meltzer, eds., Monetary and Fiscal Policies and Their Application, Camecie-Rochester Conference Series on Public Policy Vol. 20 (North Holland, Amsterdam, Spring 1984).

"Inflation and Indexation: Israel," in John Williamson, ed. Inflation and Indexation (Institute for International Economics, MIT Press, March 1985), pp. $57-85$.

Fischer, Stanley, and Modigliani, Franco. "Towards an Understanding of the Real Effects and Costs of Inflation," Weltwitschafliches Archiv, No. 114 (1978), pp. 810-32.

Friedman, Milton. "Monetary Correction," in Herbert Giersch et al., Essays on Inflation and Indexation (American Enterprise Institute for Public Policy Research, 1974), pp. 25-61.

Galyam, Zipora, and Hanoch, Giora. "Price Adjustment in a Period of Inflation - An Empirical Micro-Economic Model," Bank of Israel, Research Department Discussion Paper Series 84.07 (July 1984, Hebrew).

Gray, Jo Anna. "Wage Indexation: A Macroeconomic Approach," Joumal of Monetary Economics (April 1976), pp. 221-35.

Hicks, John R. Value and Capital, and ed. (Oxford, 1946),

Kleiman, Ephraim. "Monetary Correction and Indexation: The Brazilian and Israeli Experience," in Ishaq Nadizi and Alfonso $C$. Pastore, eds., Explorations in Economic Research, NBER, Vol. 4, No. 1 (Winter 1977), pp. 141-76.

"The Cost of Inflation," The Economic Quarterly No. 119 (January 1984), pp. 859-64 (Hebrew).

"Indexation in the Labor Market," in Yoram BenPorath, Michael Bruno, and Nadav Halevi, The Economy of Israel:
Maturing Through Crises, The Maurce Falk Institute for Economic Research in Israel (Jerusalem, July 1984), pp. 614-52.

"The Indexation of Public Debt in israel," The Maurice Falk insitute for Economic Research in Israel, Discussion Paper No. 85.04, (Jerusalem, May 1985).

Lewhari, David, and Liviatan, Nissan. "Risk and The Theory of Indexed Bonds," American Economic Review, Vol. 67, No. 3 (June 1977), pp. 366-75.

Litvin, Uri, and Meridor, Leora. "The Grant Equivalent of Subsidized Investments in Israel," Bank of israel Economic Review, No. 54 (April 1983), pp. 5-30.

Liviatan, Nissan, and Piterman, Sylvia. "Accelerating Infiation and Balance of Payment Crises: Israel 1973-84," in Yoram BenPorath, Michael Bruno, and Nadav Halevi, The Economy of Israel: Maturing Through Crises (The Maurice Falk Institute for Economic Research in Israel, July 1984), pp. 558-613.

Liviatan, Oded. "The Development of COLA and Other Wage Components," The Economic Quarterly (December 1982). pp. 349-57 (Hebrew).

"The Frequency of Wage Indexation Adjustments," Bank of Israel Economic Review (May 1985), pp. 37-52.

Marom. Arte. "The Effect of Intlation on the Size of the Banking Industry in tsraet," Bark of Israel, Research Department Discussion Paper Series 86.04, January 1986 (Hebrew).

McNelis, Paul. "Indexing as an Instrument for Stabilization Policy: A Suvey of Theoretical Developments and international Experience During the Last Decade" (Georgetown University, June 1985), mimeo.

Sheshinski, Eytan, and Weiss, Yoram. "Inflation and Costs of Price Adjustment," Review of Economic Studies (1977), pp. 287-309.

"Optimum Pricing Policies Under Stochastic Inflation," Review of Economic Studies (1983), pp. 513-29.

Shiffer, Zalman F. "Money and Inflation in Israel: The Transition of an Economy to High Inflation," this Review, (August/September 1982), pp. 28-40.

. "Indexation and Economic Policy." Economic Quarterly, No. 123 (December 1984), pp. 381-87 (Hebrew).

Sokoler, Meir. "The Inflation Tax on the Money Base, The Inflationary Subsidy Embodied in Cheap Credit and Their Influence on the Inflationary Process in Israel," Bank of Israel Economic Review (May 1985), pp. 3-28 (Hebrew).

Tatom, John A. "The Welfare Costs of Inflation," this Review (November 1976), pp. 9-22.

Yariv, Dan. "Estimating the Weath of the Public and its Development 1970-1982," Bank of Israel, Research Department Discus. sion Paper Series 84.10 (October 1984, Hebrew). 